\title{
Risk of field cultivation of pickling cucumber caused by unfavorable sunshine duration conditions
}

\author{
Robert Kalbarczyk \\ West Pomeranian University of Technology - Department of Meteorology and Climatology, Papieza Pawela VI \\ 3 - 71-469 - Szczecin - Poland <robertKalbarczyk@wp.pl>
}

\begin{abstract}
Solar energy, accessible to plants during sunshine from the sunrise to the sunset is of key importance in productivity of agrocenoses. The aim of the work was to determine risk of pickling cucumber cultivation caused by an unfavorable course of sunshine duration in Poland on the basis of a 40-year research period 19662005. The research into the subject was undertaken due to frequent occurrence of sunshine deficiency in Poland and its high temporal and spatial variability. Effect of solar conditions described by sunshine duration in the five development stages on the quantity of the total and marketable yield of cucumber with consideration of a linear trend of an independent variable was determined by means of multiple regression analysis. The accuracy of the equations was evaluated on the basis of, among other things, determination coefficient, average relative forecast error and the indexes: mean bias error (MBE), mean absolute bias error (MABE) and root mean square error (RMSE). Cucumber (Cucumis sativus L.) yield was confirmed for the period from the end of emergence to the beginning of flowering and from the beginning of harvesting to the end of harvesting. Cucumber yield was lower by $18 \%$ than the multiannual average in the years $1966-2005$ every $1.5-2$ years - in the case of the occurrence of the shortage in the period from the end of emergence to the beginning of flowering and by $12-15 \%$ every $2-3$ years in the period from the beginning of harvesting to the end of harvesting. In four years, out of the 40 considered ones, simultaneously in both cucumber development stages, unfavorable solar conditions occurred, causing reduction by at least 5\% in the total yield of the plant in Poland, and in three years - the marketable yield.

Key words: development, growth, reduction in yield, solar conditions
\end{abstract}

\section{Risco do cultivo de campo de pepino decapado causado por condições desfavoráveis de duração de brilho solar}

\begin{abstract}
RESUMO: A disponibilidade de energia solar para as plantas desde o nascer ao por do sol é de fundamental importância para todo agronegócio. O objetivo deste trabalho foi determinar o risco da produção de pepino (Cucumis satious L.) decapado causado pelo curso desfavorável de duração da radiação solar na Polônia, baseado em um período de 40 anos de pesquisa (1966-2005). A pesquisa foi realizada pelo fato da ocorrência frequente de deficiência de insolação na Polônia e sua alta variabilidade temporal e espacial. O efeito das condições solares descritas pela duração da insolação foi estudado em relação às produtividades total e comerciável de pepino, considerando uma tendência linear de uma variável independente. A precisão das equações foi avaliada com base no coeficiente de determinação, erro médio relativo de precisão e índices: erro médio de bias, erro médio absoluto de bias e raiz do erro médio quadrado. A produtividade foi analisada a partir da emergência até o início do florescimento e do inicio ao fim da colheita. A produtividade de pepino foi $18 \%$ menor em relação a media multianual dos anos 1966-2005 cada 1,5-2 anos - nos casos de falta de insolação no período emergência-florescimento e 12-15\% menor a cada 2-3 anos na colheita. Com exceção de quarto dentro dos 40 anos estudados, houve condições desfavoráveis de insolação em ambos os estádios estudados, causando uma redução de no mínimo de $5 \%$ da produção total da planta na Polônia e, excetos três anos - da produção comercial.

Palavras-chave: desenvolvimento, crescimento, redução de produtividade, condições solares
\end{abstract}

\section{Introduction}

Solar energy, accessible to plants during sunshine from the sunrise to the sunset is of key importance in productivity of agrocenoses (Medany et al., 1996; Pramanik et al., 2000; Sawan et al., 2002). In Poland sunshine duration is marked by high temporal and spatial variability and in none of the calendar seasons it exceeds $50 \%$ of potential sunshine (Podstawczynska, 2003; Kalbarczyk et al., 2006). In most of Poland there occurs an increase in sunshine duration in May and August and a decrease in September; in spring in the southern and central parts of the country, in summer in the south-western part and in autumn in the central-western part of Poland (Kozminski and Michalska, 2004). A relationship between yields of crop plants as well as the course of growth and development on sunshine duration or intensity of solar radiation was shown by Makowiecki (1985), Lykowski (1984), Rao et al. (1998), Caliskan et al. (2008), Kumar et al. (2008) and Kalbarczyk (2009). The effect of solar conditions on the quantity of yield of crop plants and on the course of growing is not strictly determined; thus, we can still search for their optimal use.

In Poland field cucumber (Cucumis satious L.) cultivation even in areas which are more favorable climatically is re- 
lated to a certain risk, consisting in reduced crop yield of the fruits. Selection of suitable regions for cultivation of crop plants, including cucumber, should be based not only on the knowledge of soil conditions and agrotechnical recommendations but also on the knowledge of temporal and spatial distribution of unfavorable meteorological elements (Liebig, 1985; Liebig and Krug, 1991; Tsai et al., 1996; Medany et al., 1999). Climatic risk of cultivation of the characterized plant can be minimized taking proper decisions before the start of production.

Therefore, the aim of the work was to assess potential reduction in field cucumber yield in Poland caused by sunshine duration deficiency and to determine frequency of its occurrence in the years 1966-2005.

\section{Material and Methods}

Data about cultivation conditions and conditions of cucumber growth were surveyed and also about the development obtained in precise cultivar experiments conducted in experimental stations situated in whole Poland in the years 1966-2005 (Figure 1). The information made available by the Research Centre for Cultivar Testing (COBORU) concerned tested soil conditions, the level of used technique of crop production, the quantity of yield (total and marketable), the following dates: sowing, the beginning and the end of harvesting and also the occurrence of basic phenophases (the end of emergence, the beginning of flowering and the beginning of fruit-setting). The starting materials came from 28 stations of COBORU collected for the successive years of the 1966-2005 multiannual period, excluding two years: 2003 and 2004, when field experiments were not carried out (Figure 1). Domestic averages (calculated from all stations) of the quantities of the total and marketable cucumber yield and sunshine duration in the successive years were also used: 2006, 2007, 2008 and 2009. The experimental data of

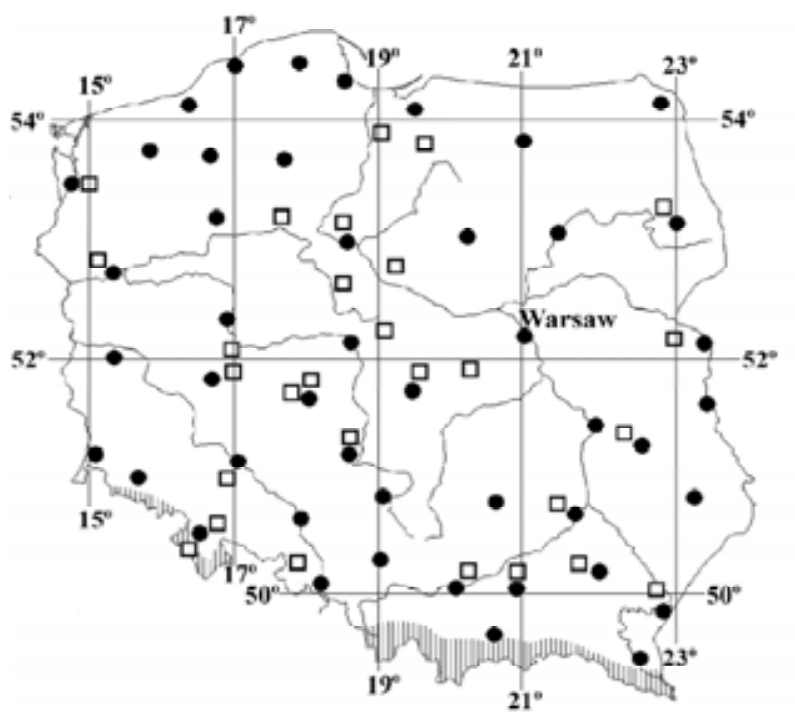

Figure 1 - Location of meteorological stations of IMGW ( and COBORU stations $(\square)$ in which experiments on cucumber cultivation in Poland were conducted.
COBORU were collected for all the most common in cultivation pickling cucumber varieties examined in a given year which after averaging were taken as a collective standard of the described plant.

The experiments were located on typical soils for cucumber cultivation, classified as very good and good wheat complexes and a very good rye complex of a slightly acid $\mathrm{pH}$. Usually cereals served as a fore-crop for cucumber. In autumn organic manure was used at a dose of $30-40 \mathrm{t} \mathrm{ha}^{-1}$, or, as a substitute, well-decayed compost at a dose of 40-60 $\mathrm{t} \mathrm{ha}^{-1}$. In spring mineral fertilization was used, which, depending on the applied organic manure and current soil richness in nutrients, amounted to: $80-150 \mathrm{~kg} \mathrm{ha}^{-1} \mathrm{~N}, 80-100 \mathrm{~kg} \mathrm{ha}^{-1}$ $\mathrm{P}_{2} \mathrm{O}_{5}$ and $150-200 \mathrm{~kg} \mathrm{ha}^{-1} \mathrm{~K}_{2} \mathrm{O}$.

The study also used data concerning sunshine duration in the following five development stages of cucumber: sowing - the end of emergence, the end of emergence - the beginning of flowering, the beginning of flowering - the beginning of fruit-setting, the beginning of fruit-setting - the beginning of harvesting and the beginning of harvesting the end of harvesting. The data were collected not only from the 28 stations of COBORU but also from 46 meteorological stations of IMGW in the years 1966-2005 (Figure 1). Sunshine duration was characterized taking into account temporal variability and examining a linear trend for the whole country and for a single research station and spatial variability in the perspective of the 1966-2005 multiannual average and in extreme years, i.e. those with the best and the worst solar conditions but only for these cucumber development stages of which sunshine duration significantly $(p \leq 0.01)$, determined yield of the described plant. The research excluded sub-mountainous regions, situated in the south-west and the south-east of the country, of which highly diversified physiographical conditions were insufficiently represented because of the lack of experimental and meteorological stations and also because of field cultivation usually occurred up to $500 \mathrm{~m}$ above sea level (Figure 1).

Effect of sunshine duration in the five cucumber development stages on the quantity of the total and marketable yield was determined with the use of curvilinear regression. In the multiple regression equation the total yield or the marketable yield were a dependent variable; sunshine duration in a given development stage and a linear trend, i.e. the successive years of the analyzed multiannual period of 19662005 , were independent variables. In the regression equation, information on soil conditions and fertilization was not taken into account as it did not differentiate the yield quantity considered in the research. The lack of differences was confirmed with the $t$-Student test. Significance of structural parameters of multiple regression and significance of the whole equation were assessed respectively with the $t$-Student test and the $F$-Snedecor test and fitting of empirical data to the regression function line on the basis of determination coefficient $R^{2}(\%)$ and a coefficient describing differences between standard deviation of a dependent variable and a standard error of equation estimation (Std - Sy). To verify regression equations a relative forecast error was also used, determined according to the equation 1 : 
RFE $=\frac{y-y_{p}}{y} \cdot 100 \%$

and an average relative forecast error for all analyzed COBORU stations and all considered years of the 1966-2005 period, which was calculated based on equation 2:

$A R F E=\frac{1}{n} \sum_{j=1}^{\infty}|R F E|$

where: $y$ - actual yield $\left(\mathrm{t} \mathrm{ha}^{-1}\right), y_{p}$ - yield calculated according to the equation $\left(\mathrm{t} \mathrm{ha}^{-1}\right), n$ - number of years in a time series (number of stations $\times$ number of years).

An additionally used test of evaluation accuracy was determining how many times a relative forecast error in the analyzed multiannual 1966-2005 period amounted to $|R F E| \leq 5 \%$ (a very good forecast) and $5 \%<R F E \mid \leq 10 \%$ (a good one). The prediction quality of regression equations was also verified on the basis of independent material which was not directly used during their formation. In the case of four years: 2006, 2007, 2008 and 2009 for the whole country (a mean of all COBORU stations), the following indexes were determined: mean bias error (MBE), mean absolute bias error (MABE) and root mean square error (RMSE) (Robaa, 2008; Bakirci, 2009).

Risk of cucumber cultivation in Poland caused by sunshine duration deficiency was determined at $p \leq 0.01$, through multiple regression equations, determining threshold values for sunshine duration when reduction by at least $5 \%$ in the total and marketable yield occurs. Next, an average value of sunshine duration, but only calculated for those years when it exceeded earlier specified threshold values, was substituted into each of the formed equations describing the effect of solar conditions in a given development stage on the quantity of the total and marketable yield. Substituting them into the equations, yield for each considered station of COBORU and IMGW, conditioned by average occurrence of unfavorable solar conditions, was calculated. Differences between the multiannual actual yield of cucumber determined for whole Poland in 1966-2005 and the yield calculated according to the above-described procedure enabled determination of potential reduction in yield caused by an unfavorable course of sunshine duration, separately for the total yield and marketable yield (Kalbarczyk and Kalbarczyk, 2006).

\section{Results}

Cucumber yield was affected by sunshine duration (at $p \leq 0.01)$ in two out of the five development stages of the plant. Sunshine duration deficiency in the periods from the end of emergence to the beginning of flowering (Ee-Bf) and from the beginning of harvesting to the end of harvesting (Bh-Eh) most strongly contributed to reduction in the total and marketable yield (Table 1). Determination coefficients determined for these relationships oscillated between 41.6 and $51.9 \%$, and the strongest relationship was shown between the total yield and sunshine duration in the period $\mathrm{Bh}-\mathrm{Eh}$. The equations were marked by a smaller error of equation estimation than natural variability of a dependent variable. Index Std - Sy oscillated between 1.3 and $2.1 \mathrm{t} \mathrm{ha}^{-1}$ and the biggest difference was found for the equation with the strongest relationship between the analyzed variables.

Average relative forecast error calculated in the successive years of the 1966-2005 multiannual period, for the regression equations, oscillated between 9.1 and $10.2 \%$. Very good $(0-5 \%)$ and good $(5-10 \%)$ forecasts, out of all the forecasts made, constituted from about 74 to $88 \%$, of which very good ones - constituted, on average, $35 \%$, and good ones - $45 \%$. Better forecasts were made for equations describing effect of sunshine duration on the total yield of cucumber, worse ones on the marketable yield. The last element of the evaluation of the formed equations was an attempt at using them to calculate domestic cucumber yield in the years which were not included in the proper analysis, namely in: 2006, 2007, 2008

Table 1 - Relationships of cucumber yield to sunshine duration in the development stages from the end of emergence to the beginning of flowering (Ee-Bf) and from the beginning of harvesting to the end of harvesting (Bh-Eh) in Poland, taking into account the linear trend through 1966-2005.

\begin{tabular}{|c|c|c|c|c|c|c|c|c|c|}
\hline \multirow{3}{*}{ Regression equations } & \multirow{3}{*}{$\begin{array}{l}\text { Model } \\
\text { no. }\end{array}$} & \multirow{3}{*}{$\begin{array}{l}\text { Development } \\
\text { stage }\end{array}$} & \multicolumn{2}{|c|}{ Variable } & \multicolumn{5}{|c|}{ Characteristics } \\
\hline & & & \multirow[t]{2}{*}{$y$} & \multirow[t]{2}{*}{$S D$} & \multirow[t]{2}{*}{$R^{2}$} & \multirow[t]{2}{*}{ Std - Sy } & \multirow[t]{2}{*}{ ARFE } & \multicolumn{2}{|c|}{$\begin{array}{l}\text { frequency of the } \\
\text { occurrence of } \\
\mid \text { RFE | in range }\end{array}$} \\
\hline & & & & & & & & $0-5$ & $5-10$ \\
\hline & & & $\mathrm{tha}^{-1}$ & h per day & $\%$ & $\mathrm{t} \mathrm{ha}^{-1}$ & --------- & --- \% ---- & $\overline{-----}$ \\
\hline $\begin{array}{l}y_{t}=-814.4^{* * *}+0.4 Y^{* * *}+14.3 S D^{* * *} \\
-0.9 \mathrm{SD}^{2 * * *}\end{array}$ & 1 & \multirow{2}{*}{$\mathrm{Ee}-\mathrm{Bf}$} & 33.2 & 7.2 & 45.8 & 1.7 & 9.8 & 36.1 & 46.8 \\
\hline $\begin{array}{l}y_{m}=-910.2 * * *+0.4 Y^{* * *}+7.7 S D^{* * *} \\
-0.5 \mathrm{SD}^{2 * * *}\end{array}$ & 2 & & 18.3 & & 42.4 & 1.4 & 10.1 & 33.1 & 43.5 \\
\hline $\begin{array}{l}y_{t}=-667.2^{* * *}+0.3 Y^{* * *}+11.5 S D^{* * *} \\
-0.7 \mathrm{SD}^{2 * * *}\end{array}$ & 3 & \multirow{2}{*}{ Bh-Eh } & 33.2 & 6.9 & 51.9 & 2.1 & 9.1 & 38.7 & 49.1 \\
\hline $\begin{array}{l}y_{m}=-870.7 * * *+0.4 Y^{* * *}+5.4 S D^{* * *} \\
-0.4 \mathrm{SD}^{2 * * *}\end{array}$ & 4 & & 18.3 & & 41.6 & 1.3 & 10.2 & 32.4 & 41.9 \\
\hline
\end{tabular}

$R^{2}$ - determination coefficient (\%), Std - Sy - difference between a standard deviation of a dependent variable and a standard error of equation estimation $\left(\mathrm{t} \mathrm{ha}^{-1}\right), A R F E$ - average relative forecast error (\%), RFE - relative forecast error (\%), $Y$ - linear trend of the yield, i.e., the successive years of the 1966-2005 multiannual period, $* * *$ significant at $p \leq 0.01, y-$ average multiannual yield $\left(\mathrm{t} \mathrm{h}^{-1}\right), y_{t}-\mathrm{total}_{\mathrm{jiel}}$ $\left(\mathrm{t} \mathrm{ha}^{-1}\right), y_{m}$ - marketable yield $\left(\mathrm{t} \mathrm{ha}^{-1}\right), S D$ - average multiannual sunshine duration (h per day) 
and 2009 (Table 2). It results from this analysis that the difference between the actual yield and the forecast yield (MBE) oscillated between -0.95 (equation 3 ) and $3.8 \mathrm{t} \mathrm{ha}^{-1}$ (equation 4). The predictions differed from the actual value of the forecast variable (MABE) on average by between 1.22 (equation 2) and $4.27 \mathrm{t} \mathrm{ha}^{-1}$ (equation 4 ). Root mean square error (RMSE) oscillated from 1.67 to $5.76 \mathrm{t} \mathrm{ha}^{-1}$; it was highest for equation 4.

Reduction by at least $5 \%$ was recorded with sunshine duration amounting to $\leq 6.5$ and $\leq 6.2 \mathrm{~h}$ per day - in the case of the total yield and $\leq 6.4$ and $\leq 5.8 \mathrm{~h}$ per day - in the case of the marketable yield; higher threshold values in both cases were determined in the period Ee-Bf, and lower ones in the period Bh-Eh (Table 1, Figure 2). With $\leq 6.0 \mathrm{~h}$ per day for the total yield and with $\leq 5.9 \mathrm{~h}$ per day for the marketable yield, i.e. respectively, on average, by 1.2 and $1.3 \mathrm{~h}$ per day below the multiannual average values of sunshine duration in the period from the end of emergence to the beginning of flowering reduction by $10 \%$ in cucumber yield was recorded, and respectively with $\leq 5.3$ and $\leq 5.2 \mathrm{~h}$ per day - by as much as $20 \%$.

Intensity of the effect of sunshine duration in the period from the end of emergence to the beginning of flowering on the quantity of both considered types of cucumber yield was similar; on the other hand, in the period from the beginning of harvesting to the end of harvesting it was slightly more diverse. The total yield of cucumber was lower by $1966-2005$ with sunshine duration in the period from the beginning of harvesting to the end of harvesting amounting to $\leq 5.7 \mathrm{~h}$ per day - in the case of the total yield and $\leq$ $5.2 \mathrm{~h}$ per day - in the case of the marketable yield, and respectively with $\leq 5.3$ and $\leq 4.7 \mathrm{~h}$ per day as much as by $15 \%$. In Poland however, reduction in cucumber yield caused by unfavorable solar conditions was not the same in all regions of the country (Figure 3). In the case of the cucumber total yield reduction caused by sunshine duration deficiency in two periods oscillated in most of Poland between 12 and 18\% in the period from the end of emergence to the beginning of flowering and between 9 and $15 \%$ in the period from the beginning of harvesting to the end of harvesting; it was similar in the case of the marketable yield - respectively between 12 and $18 \%$, and between 9 and $12 \%$.

The lowest losses, amounting to below $12 \%$, in the total and marketable yield of cucumber resulting from sunshine duration deficiency in the period Ee-Bf occurred in the central-eastern, north-eastern and central parts of Poland. In the case of the marketable yield the area with the lowest losses

Table 2 - Statistical evaluation of multiple regression equations, presented in Table 1, 2006-2009.

\begin{tabular}{lcccc}
\hline \multirow{2}{*}{ Index } & \multicolumn{4}{c}{ Model no. } \\
\cline { 2 - 5 } & 1 & 2 & 3 & 4 \\
\hline MBE $\left(\mathrm{t} \mathrm{ha}^{-1}\right)$ & 1.45 & 1.02 & -0.95 & 3.80 \\
MABE $\left(\mathrm{t} \mathrm{ha}^{-1}\right)$ & 1.90 & 1.22 & 1.55 & 4.27 \\
RMSE $\left(\mathrm{t} \mathrm{ha}^{-1}\right)$ & 2.55 & 1.67 & 2.51 & 5.76 \\
\hline
\end{tabular}

MBE - mean bias terror $\left(\mathrm{t} \mathrm{ha}^{-1}\right)$, MABE - mean absolute bias error $\left(\mathrm{t} \mathrm{ha} \mathrm{a}^{-1}\right)$, RMSE - root mean square error $\left(\mathrm{t} \mathrm{ha}^{-1}\right)$. covered much smaller part of the country, only central-eastern Poland up to Warsaw and north-eastern part of the country; the biggest losses in yield, amounting to above $18 \%$, occurred in the western and southern parts of the country and in the case of the marketable yield also in the southeastern part. Spatial distribution of variability of the course of potential reduction in cucumber yield caused by sunshine duration deficiency at the end of the growing season (BhEh) was less diverse than in the period Ee-Bf. In the period from the beginning of harvesting to the end of harvesting reduction in cucumber yield, oscillating between 9 and $12 \%$, covered the biggest part of the country, and like in the period Ee-Bf - the lowest losses in yield, amounting to below $9 \%$, occurred in eastern Poland, and the biggest in the south.

In Poland, frequency of the occurrence of sunshine duration deficiency causing reduction by $5 \%$ in cucumber yield in the period from the end of emergence to the end of flowering amounted to about 33 and $31 \%$, respectively for 6.5 and $6.4 \mathrm{~h}$ per day, and in the period from the beginning of harvesting to the end of harvesting about 34 and $23 \%$, respectively for 6.2 and $5.8 \mathrm{~h}$ per day (Figure 4). Sunshine duration lower than 5.1 and $4.8 \mathrm{~h}$ per day, respectively in the
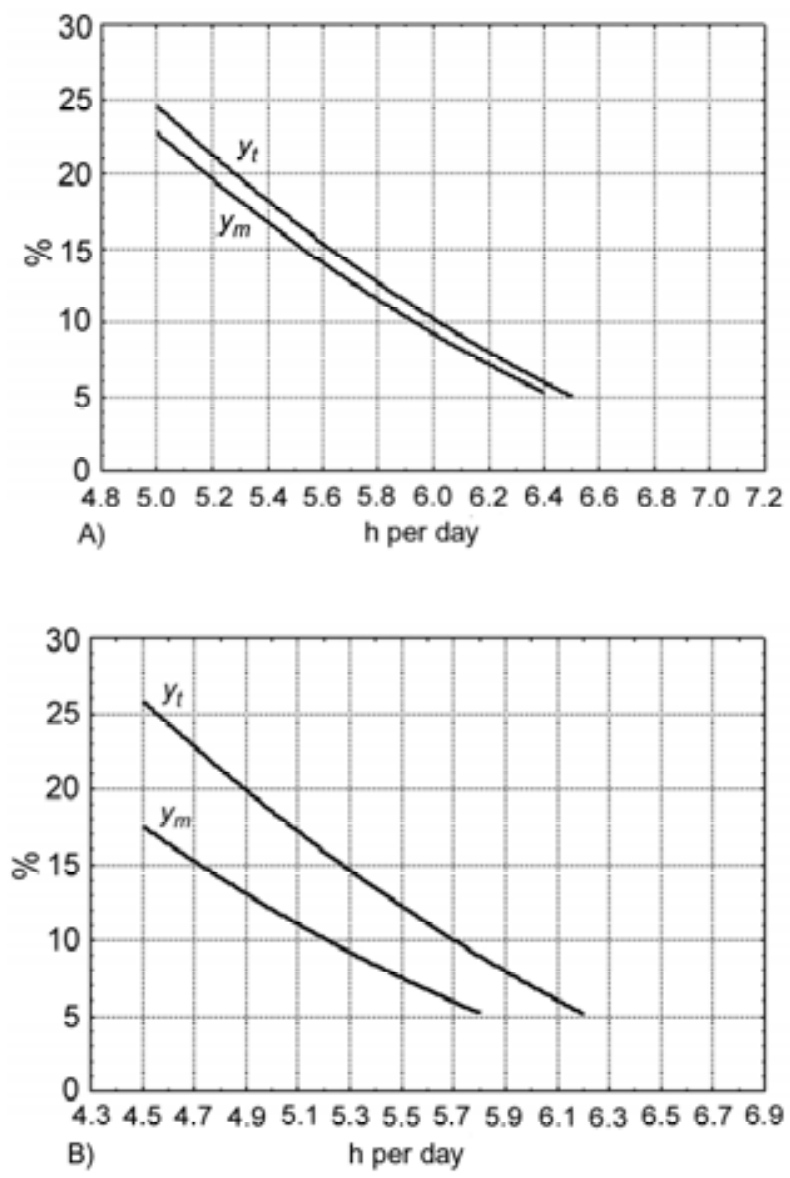

Figure 2 - Potential reduction $(\%)$ in the total yield $\left(y_{t}\right)$ and the marketable yield $\left(y_{m}\right)$ of cucumber in Poland caused by sunshine duration deficiency in the development stages: Ee-Bf (A) and Bh-Eh (B) (yield calculated on the basis of regression equations presented in Table $1)$. 

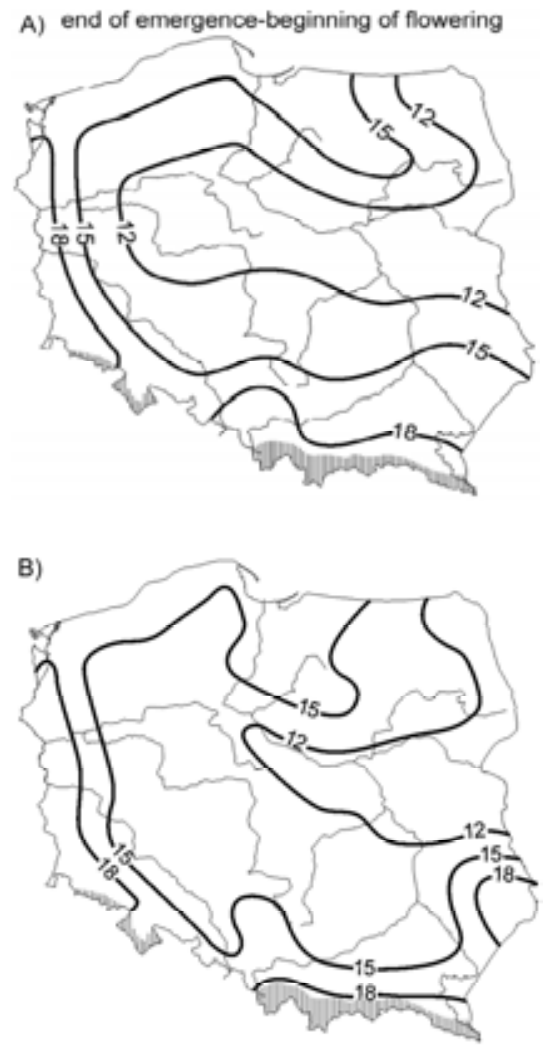

A) beginning of harvesting-end of harvesting

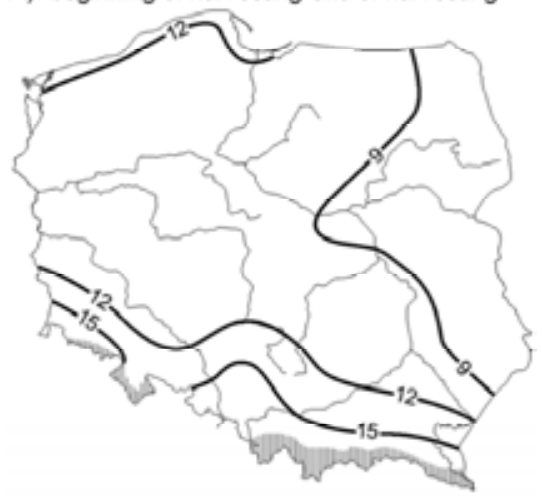

B)

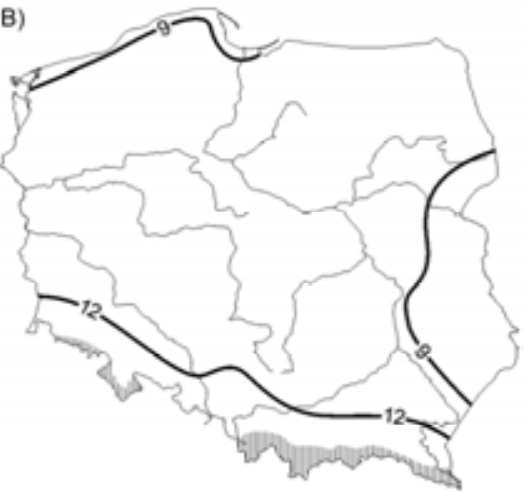

Figure 3 - Spatial distribution of potential reduction (\%) in the total yield (A) and the marketable yield (B) of cucumber in Poland caused by sunshine duration deficiency in the development stages: Ee-Bf and Bh-Eh (yield calculated on the basis of regression equations presented in Table 1).

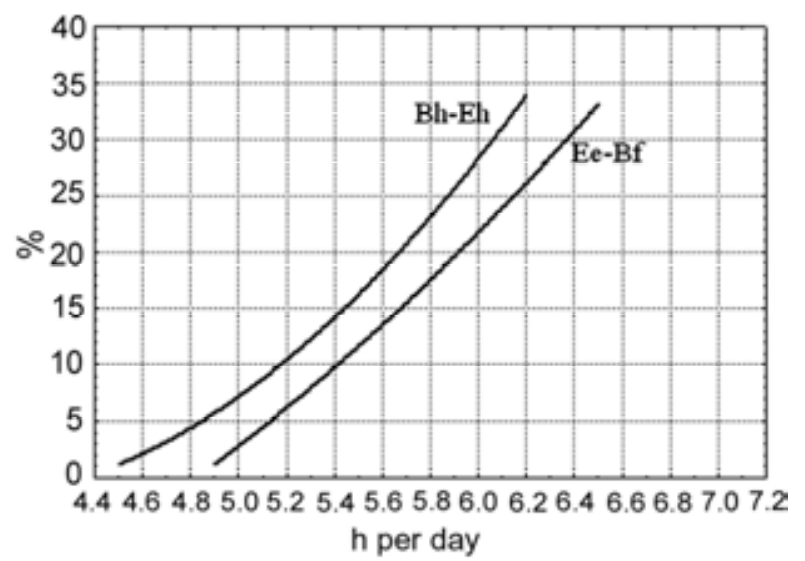

Figure 4 - Frequency of the occurrence (\%) of sunshine duration deficiency in Poland in the cucumber development stages: Ee-Bf and Bh-Eh.

periods Ee-Bf and Bh-Eh occurred with frequency not exceeding $5 \%$. Distribution of the course of frequency of sunshine duration occurrence in the period Ee-Bf, $\leq 6.5$ and $\leq$ $6.6 \mathrm{~h}$ per day, was very similar and oscillated between below $20 \%$ and even above $60 \%$ (Figure 5). Least frequently, on average every five years, such values of sunshine duration deficiency occurred in the eastern and northern parts of Poland, situated along the coast of the Baltic, and most frequently, on average every two years, in the southern part of Poland; in some regions of southern Poland even more often - every 1.5 year. However, in most regions of Poland, situated in the western and central parts, risk of cucumber cultivation caused by sunshine duration deficiency in the period from the end of emergence to the end of flowering oscillated between 20 and $30 \%$, i.e. it occurred averagely every 3-5 years. On the other hand, sunshine duration deficiency in the period from the beginning of harvesting to the end of harvesting, calculated as $\leq 6.2 \mathrm{~h}$ per day, least frequently, on average every ten years, occurred in central-eastern Poland and most frequently, on average every 2-2.5 years - in the south.

The biggest area of Poland, situated in its western and central parts was marked by moderate, from 20 to $30 \%$, risk of cucumber cultivation caused by the occurrence of insufficient sunshine duration for proper development of this plant. In the period of cucumber fruiting (Bh-Eh) sunshine duration, amounting to $\leq 5.8 \mathrm{~h}$ per day, was most frequently recorded in the south, least frequently - in almost whole eastern Poland. In 4 years, out of the 40 considered ones, unfavorable solar conditions, causing reduction by at least $5 \%$ in the total yield of the plant in Poland, occurred in both cucumber development stages in the same growing season, and only in three years out of 40 - reduction in the marketable yield.

Sunshine duration in the cucumber development periods Ee-Bf and Bh-Eh was characterized by high temporal variability in the analyzed multiannual period 1966-2005 (Fig- 
ures 6 and 7). In the period from the end of emergence to the end of flowering, average sunshine duration amounted to $7.2 \mathrm{~h}$ per day and oscillated between 4.9 in 1980 and $9.5 \mathrm{~h}$ per day in 1976, and in the period from the beginning of harvesting to the end of harvesting - on average $6.9 \mathrm{~h}$ per day and oscillated between 4.7 in 1980 and $8.6 \mathrm{~h}$ per day in 1995.

Deviations of sunshine duration values from the multiannual average in the period Ee-Bf oscillated between
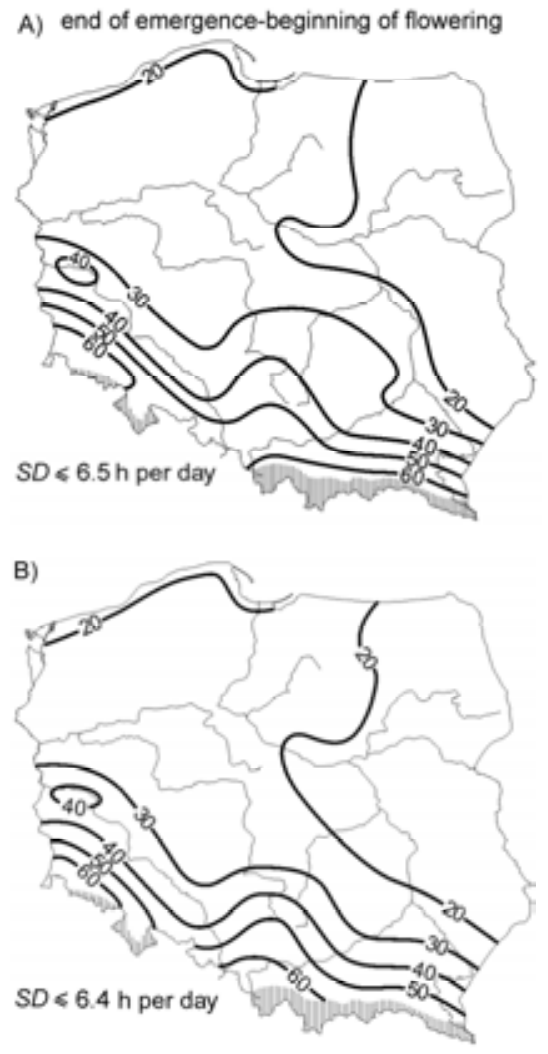

-2.3 and $2.3 \mathrm{~h}$ per day, negative ones were recorded in 16 years out of the 40 considered ones - the highest in: 1980, 1985, 1984, 1974, 1981 and 1998, and positive ones in 22 years the highest in: 1976, 1992, 1968, 1994, 1983, 1970 and 1986. The same sunshine duration as the average in the multiannual period 1966-2005 occurred only in 2 years: 1972 and 1977. Despite the fact that in the last 15 years as many as nine cases of positive deviations were recorded (1991, 1992, 1994, 1995, 1997, 2000, 2002, 2003 and 2005), sun-
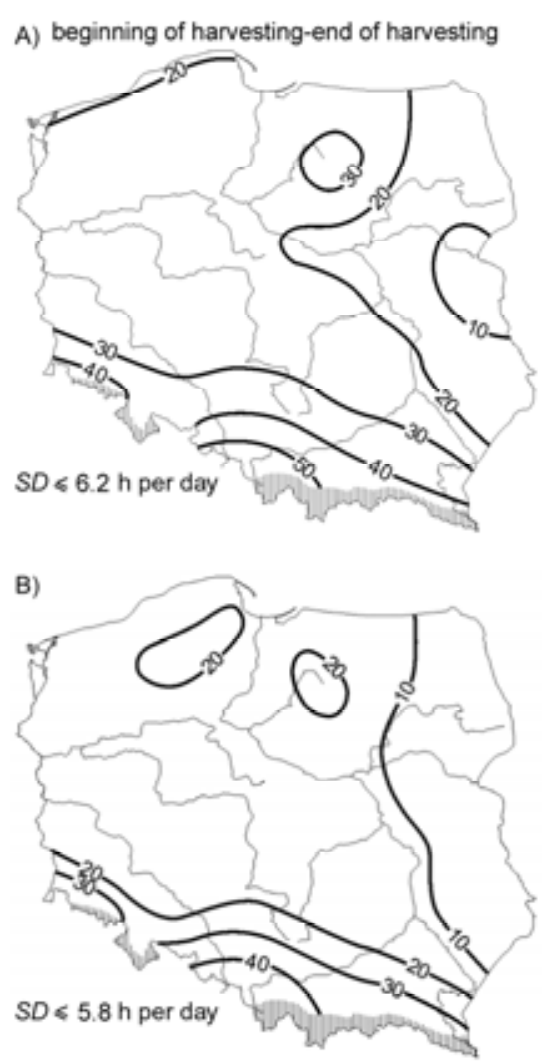

Figure 5 - Spatial distribution of frequency of the occurrence $(\%)$ of sunshine duration deficiency in the development stages: Ee-Bf and Bh-Eh, causing reduction by at least $5 \%$ in the total (A) and the marketable yield (B) of cucumber in Poland.

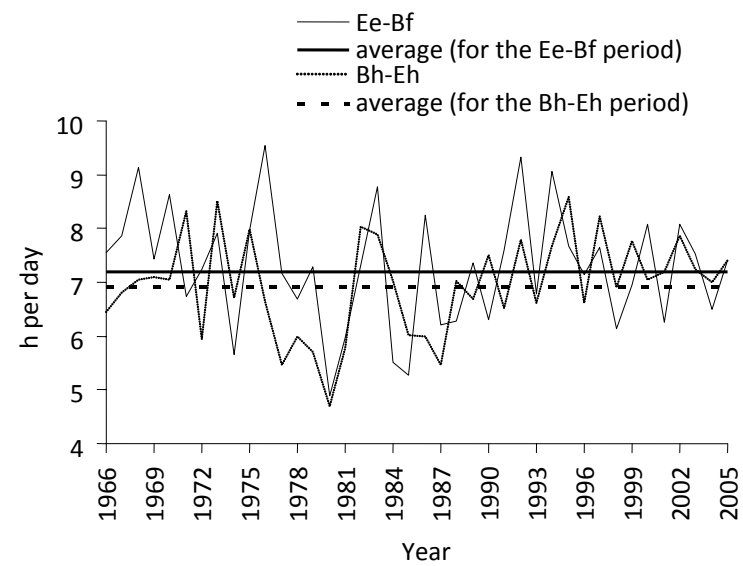

Figure 6 - Course of sunshine duration (h per day) in Poland in the cucumber development stages: Ee-Bf and BhEh.

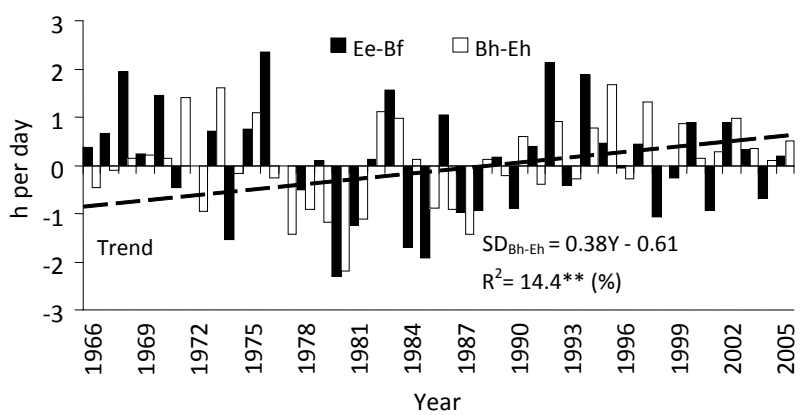

Figure / - Veviations or sunsnine duration (n per day) in a given year from the average multiannual value in Poland in the cucumber development stages: Ee-Bf and BhEh. 
shine duration in the period from the end of emergence to the end of flowering did not show a trend even at $p \leq 0.1$. However, a slight positive increase, year on year, was noticeable. In the period from the beginning of harvesting to the end of harvesting there was almost the same number of negative and positive deviations from the norm of sunshine duration, determined in the successive years of the examined 1966-2005 multiannual period, as in the period from the end of emergence to the end of flowering, but they did not always occur in the same years.

Only in seven years negative deviations from the norm occurred both in the period Ee-Bf and in Bh-Eh (1974, 1978, 1980, 1981, 1985, 1987, 1993 and 1996) and in as many as 14 years - positive ones $(1968,1969,1970,1975,1982,1983$, 1992, 1994, 1995, 1997, 2000, 2002, 2003 and 2005); during the period of the last 15 years - in eight years. Sunshine duration in the period Bh-Eh, unlike in the period Ee-Bf, was marked by a positive trend - on average, it increased by 0.38 $\mathrm{h}$ per day/10 years $\left(R^{2}=14.4 \%, p \leq 0.05\right)$. Not only for the whole country but also for single stations, situated in southwestern and central Poland, a increase in the number of hours with sunshine was proved; it oscillated between 0.3 and even $1.0 \mathrm{~h}$ per day/10 years; the highest increase occurred in the regions of Kalisz and $\mathrm{Ko}^{3} \mathrm{O}$ and also in the regions of Katowice and Cracow.

In the years 1966-2005, sunshine duration in the period from the end of emergence to the end of flowering was not only temporally but also spatially diversified; it oscillated between below 6.5 and above 8.0 h per day (Figure $8)$. The biggest number of hours with sunlight occurred
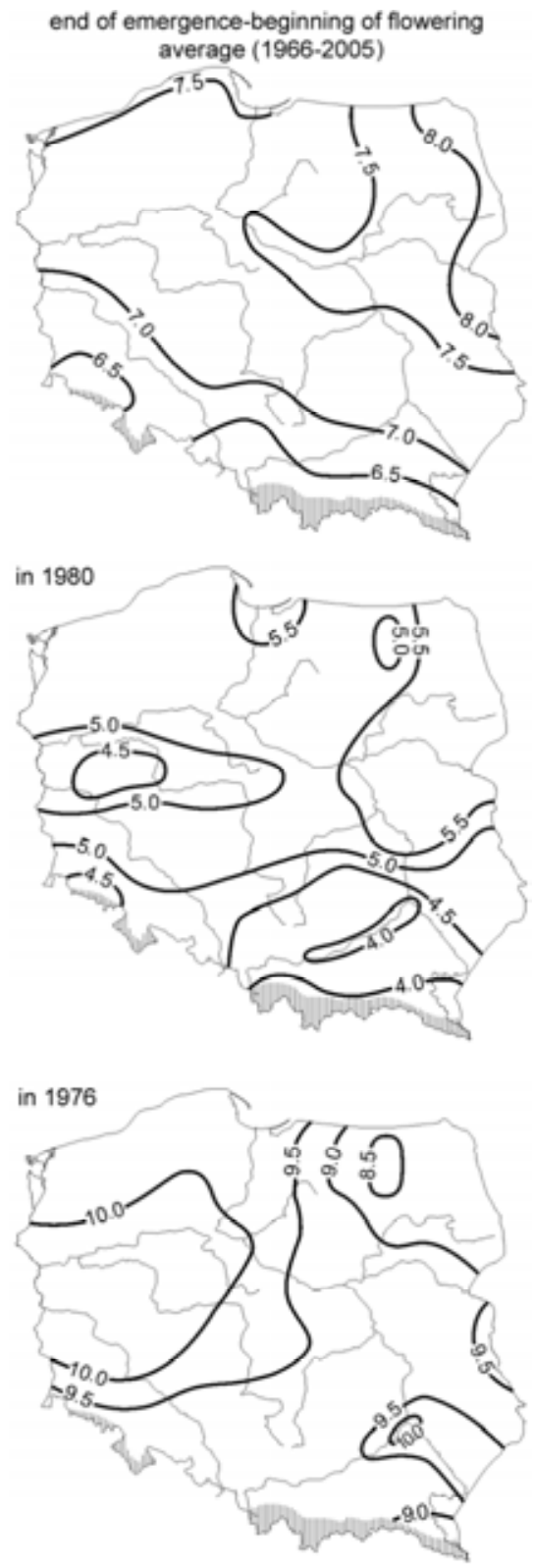
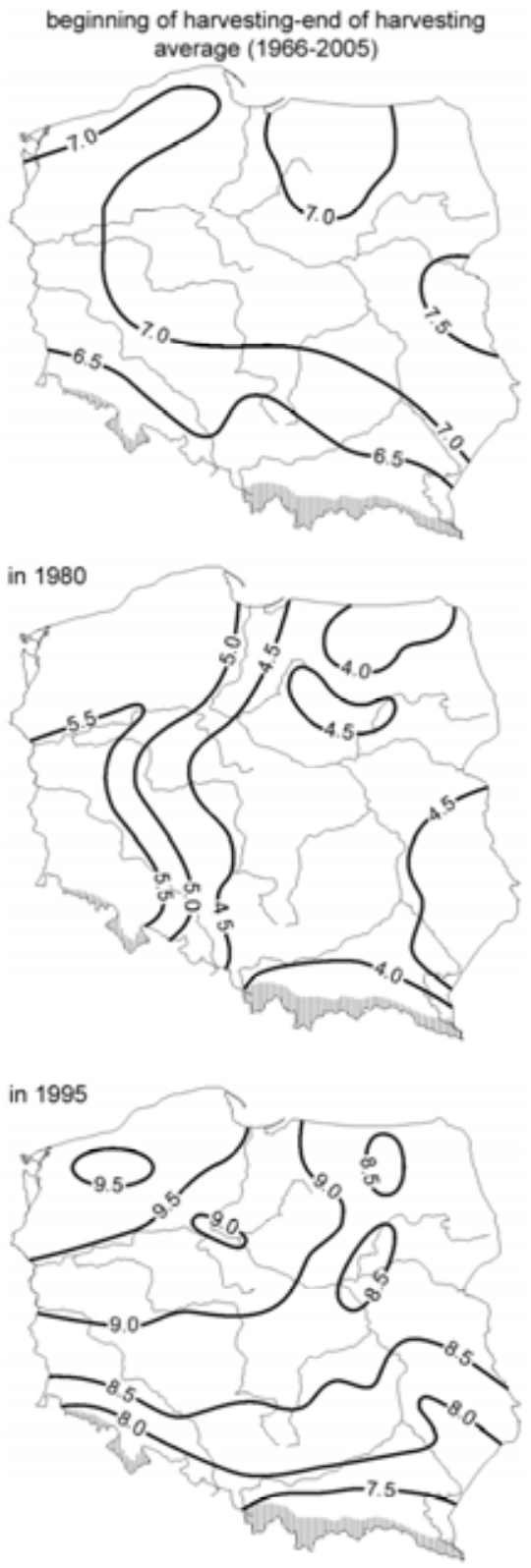

Figure 8 - Spatial distribution of sunshine duration (h) in Poland in the cucumber development stages: Ee-Bf and Bh-Eh. 
in north-eastern and central-eastern Poland, the smallest number of hours - in the south-western and south-eastern parts of the country. However, in the years when extreme sunshine duration was recorded, the spatial course of this element was different from the average multiannual distribution in the years 1966-2005. In 1980 when the lowest sunshine duration value in the whole analyzed multiannual period was noted, the number of hours with sunlight oscillated between $4.0 \mathrm{~h}$ per day in the south-east and above $5.5 \mathrm{~h}$ per day in the north and the north-east; on the other hand, in 1976 when the highest sunshine value was recorded - in most regions of Poland it oscillated between 8.5 and $10 \mathrm{~h}$ per day; in the central-west and locally in the south-east it was the highest. In the period from the beginning of harvesting to the end of harvesting, distribution of sunshine duration was various: in the 19662005 multiannual period and in 1995 - it was close to latitudinal distribution and in 1980 - close to longitudinal.

In the multiannual period and in 1980 and 1995 the smallest number of days with sunlight was recorded in the south-east, in the multiannual period also in the southwest, and in 1980 additionally in the north-east of Poland, where it amounted to, respectively, $\leq 6.5, \leq 4.0$ and $\leq 7.5 \mathrm{~h}$ per day. In the cucumber development period Bh-Eh sunshine duration in the analyzed multiannual period was the highest in the central-eastern part of the country $(\geq 7.5$ $\mathrm{h}$ per day), in 1980 - in the central-west and the southwest ( $\geq 5.5 \mathrm{~h}$ per day), and in 1995 - in the north-west of Poland ( $\geq 9.5 \mathrm{~h}$ per day).

\section{Discussion}

There are no research studies in the literature on risk assessment of cucumber field cultivation caused by unfavorable meteorological conditions - among others, by solar conditions - not only for Poland but also for other countries where they occur during the growing season of the characterized plant. Also there are few studies describing effect of solar conditions on growth, development and yield of cucumber (Liebig, 1985; Liebig and Krug, 1991; Kharkina et al., 2003; Ibarra-Jiménez et al., 2008; Kalbarczyk, 2009), but there are a lot more studies devoted to optimization of cultivation and cropping physiology of the characterized plant (Peil and López-Gálvez, 2002; Talanov et al., 2005; Piszczek and Glowacka, 2008). Cucumber ontogenesis, from seed germination to final stages of ageing and their death, is controlled by light. Solar energy is converted by plant in the process of photosynthesis into chemical energy which is used to maintain their life functions and its excess is accumulated as reserve substances which are the source of food for the human.

Induced by light, the processes of photomorphogenesis are regulated by photoreceptors absorbing near ultraviolet rays, blue light, red light and far red light (Pei et al., 2005; Mi et al., 2008). It results from the scientific reports by Talanov et al. (2005) who examined effect of high and low temperature of a habitat $\left(35\right.$ and $\left.15^{\circ} \mathrm{C}\right)$ and day duration $(8,12$ and $16 \mathrm{~h}$ ) on changes of efficiency rate of $\mathrm{CO}_{2}$ assimilation by cucumber plants that low temperature and a short day increased the value of this rate and simultaneously decreased the weight of biomass of the described plant. On the other hand, Kharkina et al. (2003) investigated influence of habitat temperature with illumination of intensity of $100 \mathrm{~W} \mathrm{~m}^{-2}$ and a 12-hour day on parameters describing the dynamics of sprout growth and rooting of cucumber plants. The highest values of the analyzed parameters were obtained with stable daily temperature of soil and air amounting to 25 and $20^{\circ} \mathrm{C}$, respectively in the case of the first and second set of indexes. It results from the research by Marcelis (1994), conducted on the basis of greenhouse experiments, that with an increase in solar radiation the dry mass of a vegetative part of a stem grows, but the total share of the dry mass of this part decreases.

An increase in radiation causes an increase in production of the dry mass of a stem less than production of the dry mass of leaves and petioles. On the other hand, Liebig and Krug (1991) created a model, taking into consideration two meteorological elements, solar radiation and air temperature, to weekly forecast the quantity of cucumber yield and Medany et al. (1996), on the basis of field and glasshouse research, determined impact of the two elements on the growth rate of the dry mass of the plant. Scheunemann et al. (1990) forecast dates and duration of cucumber harvesting depending on the date of sowing and on the basis of air temperature and sunshine duration. According to them, the beginning of cucumber harvesting occurs when in the growing season the sum of sunshine duration amounts to $350 \mathrm{~h}$ and the sum of air temperature - $950-1000^{\circ} \mathrm{C}$. Górka (1987) determined higher sums of air temperature. According to him they oscillate in Poland between $1055^{\circ} \mathrm{C}$ and $1217^{\circ} \mathrm{C}$.

The growth rate of cucumber fruits depending on the course of solar conditions was researched by few scientists (Marcelis, 1993; Medany et al., 1999). At the initial stage of fruit development the influence of radiation on the growth rate depends on the presence of earlier developed fruits because of the domination of internal fruits. At the end of fruiting lessened intensity of solar radiation reduces the growth rate of all fruits irrespective of their age and presence of other cucumber fruits (Marcelis, 1993). Medany et al. (1999) assessed the growth rate of cucumber fruits under in greenhouse conditions, depending on air temperature at night, cultivation season and light conditions modified by various polyethylene plastics. The fruits grew fastest at the temperature of $18^{\circ} \mathrm{C}$ in conditions with strongest illumination and regardless of the season of the year.

Peil and López-Gálvez (2002) found that with increased planting of cucumber, from 1.8 to $2.3 \mathrm{~m}^{-2}$, the total biomass of the overground parts of the plant and the number and biomass of fruits on the plant decrease; the rate of growth and development is also reduced, but only until the flowering phase. Liebig (1985) observed that weekly cucumber cropping depends mostly on solar radiation and, next, on the age of a plant and air temperature. Sysoeva and Markovskaya (2006) researched effect of light and temperature on the growth rate of, among other plants, cucumber. According to these researchers optimal light and thermal conditions are: day duration amounting to $13 \mathrm{~h}$, light intensity - $130 \mathrm{klx}$ and average temperature $-30^{\circ} \mathrm{C}$. 
Piszczek and Glowacka (2008) evaluated the effect of the colour of light on cucumber planting and found that cucumber plants growing under lamps with blue light, compared with daylight, were higher, had longer internodes, a thicker stem and a higher content of dry mass in the fresh mass of shoots. According to Piszczek and Glowacka (2008), with quantum irradiation of intensity amounting to $60 \mu \mathrm{mol}$ $\mathrm{m}^{-2} \mathrm{~s}^{-1}$ the content of chlorophyll and carotenoids was bigger in the leaves of plants growing in daylight and the content of anthocyanins was not reliant on the colour of light and the intensity level of quantum irradiation. On the other hand, Ibarra-Jiménez et al. (2008) investigated effect of eight screens of different colours on accumulation of heat in the root zone, the rate of photosynthesis and the quantity of cucumber yield. Almost all of the screens used in the experiment on cucumber cultivation contributed to an increase in yield. Ibarra-Jiménez et al. (2008) suggest that the colour of a screen should be individually adjusted to a climatic zone. On the other hand, Pramanik et al. (2000) in hydroponical research found that with an increase in temperature and day lengthening the amount and rate of secretion of organic acids by cucumber roots increase.

Comparatively many works concern the characteristics of temporal and spatial distribution of solar conditions, analyzed most often according to months (Aksoy, 1999; Power, 2003; Darula and Kittler, 2004; Cancillo et al., 2005; Dolinar, 2006; Sanchez-Lorenzo et al., 2008; El-Shimy, 2009; Fadare, 2009), less frequently according to seasons and much less according to plant development stages (Power, 2003; Matzarakis and Katsoulis, 2006). Therefore, it is difficult to compare the obtained results of the current work with other results. Besides, in those works variability of solar conditions is described not only by sunshine duration but also by intensity of solar radiation and it is examined on the basis of multiannual periods of different length, often in different than in Poland climatic conditions (Mefti et al., 2003; Rahim and Mulyadi, 2004; Moisselin and Canellas, 2005; Sanchez-Lorenzo et al., 2008; Fadare, 2009; Moradi, 2009). Differences in the quantity of sunshine duration recorded at meteorological stations in Poland at the turn of the $20^{\text {th }}$ and $21^{\text {st }}$ century, in the successive months of the pickling cucumber growing season (May-September) were confirmed also by Podstawczynska (2003), Kozminski and Michalska (2004) and Kozuchowski and Degirmendzic (2005). In the years 1952-2001, an increase in sunshine duration occurred mostly in May and August, and next in June in Poland (Kozminski and Michalska, 2004), i.e. at the time partly overlapping with some development stages of cucumber (Ee-Bf and Bh-Eh), in which an increase in this meteorological element was proved. According to these researchers, variability of sunshine in Poland is diverse, the highest occurs in the south-western part. Also Kozuchowski and Degirmendzic (2005), on the basis of the 1971-2003 multiannual period, found the highest increase in the number of hours with sunlight in May (from $12.1 \mathrm{~h} / 10$ years in SW Poland to $26.5 \mathrm{~h} / 10$ years in $\mathrm{NE}$ ), next in July (from $4.1 \mathrm{~h} / 10$ years in central Poland to $17.8 \mathrm{~h} / 10$ years in NE) and in August (from $1.5 \mathrm{~h} / 10$ years in SW Poland to $18.8 \mathrm{~h} / 10$ years in NE).

\section{Conclusion}

Reduction by at least $5 \%$ in cucumber yield occurred with sunshine duration amounting to $\leq 6.5$ and $6.4 \mathrm{~h}$ per day in the case of the total yield and $\leq 6.2$ and $5.8 \mathrm{~h}$ per day in the case of the marketable yield, respectively in the periods: the end of emergence - the beginning of flowering and the beginning of harvesting - the end of harvesting. Sunshine duration deficiency in the period from the end of emergence to the beginning of flowering caused reduction in the total and marketable yield from below 12 to $18 \%$ (the highest reduction occurred in the west and the south-east), and in the period from the beginning of harvesting to the end of harvesting - from below 9 to above $12 \%$ in the case of the marketable yield or to above $15 \%$ in the case of the total yield, (the highest occurred in the south of Poland). Unfavorable solar conditions prevailing in the period from the end of emergence to the beginning of flowering usually occurred every 2-5 years and conditions prevailing in the period from the beginning of harvesting to the end of harvesting every 2-10 years; in both cucumber development stages they were most frequently recorded in the south of Poland.

\section{References}

Aksoy, B. 1999. Analysis of changes in sunshine duration data for Ankara, Turkey. Theoretical and Applied Climatology 64: 229-237.

Bakirci, K. 2009. Models of solar radiation with hours of bright sunshine: a review. Renewable and Sustainable Energy Reviews 13: 2580-2588.

Caliskan, S.; Caliskan, M.E.; Arslan, M.; Arioglu, H. 2008. Effects of sowing date and growth duration on growth and yield of groundnut in a Mediterranean-type environment in Turkey. Field Crops Research 105: 131-140.

Cancillo, M.L.; Serrano, A.; Ruiz, A.; García, J.A.; Antón, M.; Vaquero, J.M. 2005. Solar global radiation and sunshine duration in Extremadura (Spain). Physica Scripta 118: 24-28.

Darula, S.; Kittler, R. 2004. Sunshine duration and daily courses of illuminance in Bratislava. International Journal of Climatology 24: 1777-1783.

Dolinar, M. 2006. Spatial interpolation of sunshine duration in Slovenia. Meteorological Applications 13: 375-384.

El-Shimy, M. 2009. Viability analysis of PV power plants in Egypt. Renewable Energy 34: 2187-2196.

Fadare, D.A. 2009. Modelling of solar energy potential in Nigeria using an artificial neural network model. Applied Energy 86: 14101422.

Górka, W. 1987. Valuation of agroclimatic conditions in Poland for selected vegetables. Agricultural University in Szczecin Press, Szczecin, Poland. (in Polish).

Ibarra-Jiménez, L.; Zermeño-González, A.; Munguía-López, J.; QuezadaMartín, M.A.R.; De La Rosa-Ibarra, M. 2008. Photosynthesis, soil temperature and yield of cucumber as affected by colored plastic mulch. Acta Agriculturae Scandinavica, Section B 58: 372-378.

Kalbarczyk, R.; Kalbarczyk, E. 2006. A potential decrease in the yield of potato in Poland caused by deficiency in sunshine. Polish Journal of Natural Sciences 21: 519-529.

Kalbarczyk, R.; Kalbarczyk, E.; Blaszkowska, M. 2006. Time structure of real sunshine in the Szczecin Lowlands in 2000-2004. Scientific Review Engineering and Environmental Sciences. 1: 114-122. (in Polish, with abstract in English).

Kalbarczyk, R. 2009. Use of cluster analysis in the determination of the influence of agrotechnical dates and phenological phases on field cucumber (Cucumis sativus L.) yields in Poland. Acta Scientiarum Polonorum - Hortorum Cultus 8: 63-75. 
Kharkina, T.G.; Markovskaya, E.F.; Sysoeva, M.I. 2003. Influence of thermoperiod on growth and development in cucumber. Russian Journal of Developmental Biology 34: 121-125.

Kozuchowski, K.; Degirmendzic, J. 2005. Contemporary changes of climate in Poland: trends and variation in thermal and solar conditions related to plant vegetation. Polish Journal Ecology 53: 283-297.

Kozminski, C.; Michalska, B. 2004. Variability of actual insolation in Poland. Acta Agrophysica 3: 291-305. (in Polish, with abstract in English).

Kumar, A.; Pandey, V.; Shekh, A.M.; Kumar, M. 2008. Growth and yield response of soybean (Glycine max L.) in relation to temperature, photoperiod and sunshine duration at Anand, Gujarat, India. Eurasian Journal of Agronomy 1: 45-50.

Liebig, H.P. 1985. Model of cucumber growth and yield. II. Prediction of yields. Acta Horticulturae 156: 139-154.

Liebig, H.P.; Krug, H. 1991. Response of cucumber to climate (B). Acta Horticulturae 287: 47-50.

Lykowski, B. 1984. Climatic Conditions of Development and Cropping of Soya in Poland. SGGW-AR Press, Warsaw, Poland. (in Polish, with abstract in English).

Makowiecki, J. 1985. Cropping of winter wheat in diverse natural conditions. Zakl. Narodowy im. Ossolinskich Press, Wroclaw, Poland. (in Polish, with abstract in English).

Marcelis, L.F.M. 1993. Effect of assimilate supply on the growth of individual cucumber fruits. Physiologia Plantarum 87: 313-320.

Marcelis, L.F.M. 1994. A simulation model for dry matter partitioning in cucumber. Annals of Botany 74: 43-52.

Matzarakis, A.P.; Katsoulis, V.D. 2006. Sunshine duration hours over the Greek region. Theoretical and Applied Climatology 83: 107120.

Medany, M.A.; Wadid, M.M.; Abou-Hadid, A.F. 1999. Cucumber fruit growth rate in relation to climate. Acta Horticulturae 491: 107-112.

Medany, M.A.; Abou-Hadid, A.F.; Shorp, T.H. 1996. Cucumber models in relation to radiation and temperature. Cahiers Options Méditerranéennes 31: 167-176.

Mefti, A.; Bouroubi, M.Y.; Adane, A. 2003. Generation of hourly solar radiation for inclined surfaces using monthly mean sunshine duration in Algeria. Energy Conversion and Management 44: 31253141.

Mi, G.Q.; Liu, L.Y.; Dang, J.W.; Zhang, Z.X.; Ren, H.Z. 2008. Identification of low-light induced genes in cucumber (Cucumis sativus) seedlings by suppression subtractive hybridization. Scientia Horticulturae 117: 89-94

Moisselin, J.M; Canellas, C. 2005. French homogenized sunshineduration long-term series. Comptes Rendus Geoscience 377: 729734. (in French, with abstract in English).

Moradi, I. 2009. Quality control of global solar radiation using sunshine duration hours. Energy 34: 1-6.

Pei, X.B.; Li, S.C.; Cai, R. 2005. Effects of sustained low intensity light treatment on growth development and photosynthetic rate of cucumber. Journal of Anhui Agricultural University 32: 373-376.
Peil, R.M.; López-Gálvez, J. 2002. Fruit growth and biomass allocation to the fruits in cucumber: effect of plant density and arrangement. Acta Horticulturae 588: 75-80.

Piszczek, P.; Glowacka, B. 2008. Effect of the colour of light on cucumber (Cucumis sativus L.) seedlings. Vegetable Crops Research Bulletin 68: 71-80.

Podstawczynska, A. 2003. Variability of sunshine duration in Lodz in 1951-2000. Acta Universitatis Wratislaviensis - Studia Geograficzne 75: 282-291.

Power, H.C. 2003. Trends in solar radiation over Germany and an assessment of the role of aerosols and sunshine duration. Theoretical and Applied Climatology 76: 47-63.

Pramanik, M.H.R.; Nagai, M.; Asao, T.; Matusui, Y. 2000. Effects of temperature and photoperiod on phytotoxic root exudates of cucumber (Cucumis sativus) in hydroponic culture. Journal of Chemical Ecology 26: 1953-1967.

Rahim, R.; Mulyadi, B.R. 2004. Classification of daylight and radiation data into three sky conditions by cloud ratio and sunshine duration. Energy and Buildings 36: 660-666.

Rao, P.S.; Saraswathyamma, C.K.; Sethuraj, M.R. 1998. Studies on the relationship between yield and meteorological parameters of para rubber tree (Hevea brasiliensis). Agricultural and Forest Meteorology 90: 235-245.

Robaa, S.M. 2008. Evaluation of sunshine duration from cloud data in Egypt. Energy 33: 785-795.

Sanchez-Lorenzo, A.; Calbó, J.; Martin-Vide, J. 2008. Spatial and temporal trends in sunshine duration over Western Europe (1938-2004). Journal of Climate 21: 6089-6098.

Sawan, Z.M.; Hanna, L.I.; Gad El Karim, G.A.; McCuiston, W.L. 2002. Relationships between climatic factors and flower and boll production in Egyptian cotton (Gossypium barbadense). Journal of Arid Environments 52: 499-516.

Scheunemann, C.; Schonhof, I.; Vogel, G.; Fröhlich, H. 1990. Influence of elected factors for the timing of fruit vegetables. Acta Horticulturae 267: 339-347.

Sysoeva, M.I.; Markovskaya, E.F. 2006. Photothermal model of plant development. Russian Journal of Developmental Biology 37: 16-21.

Talanov, A.V.; Popov, E.G.; Kurets, V.K.; Drozdov, S.N. 2005. Effect of temperature and photoperiod on efficiency of assimilated $\mathrm{CO}_{2}$ conversion into the biomass of Cucumis sativus. Russian Journal of Plant Physiology 52: 176-181.

Tsai, J.C.; Yao, M.H.; Chi, K.S.; Liang, L.S. 1996. Studies on the relationships between climatic elements and the yield of mango in Yuching area. Journal of Agricultural Research of China 45: 186-194.

Received January 08, 2010

Accepted August 25, 2010 